\title{
What James Saw: The Bethnal Green Museum and Charles Eliot Norton
}

DOI: http://dx.doi.org/10.12775/LC.2017.003

\begin{abstract}
This paper draws upon unpublished letters from Charles Eliot Norton to Henry James regarding James's visit to the Bethnal Green Museum in London; and considers the similarities and divergences between James's review, "The Bethnal Green Museum," published in the Atlantic Monthly in 1873, and a comparable review of Norton's "The Manchester Art Exhibition," published in the same magazine some two decades earlier.
\end{abstract}

Key Words: Charles Eliot Norton, Henry James, Manchester Art Exhibition, Bethnal Green Museum

\section{Co widział James: Bethnal Green Museum i Charles Eliot Norton}

Streszczenie: Artykuł odwołuje się do niepublikowanych listów Charlesa Eliota Nortona do Henry'ego Jamesa. Listy dotyczą wizyty Jamesa w Bethnal Green Museum w Londynie. Autorka omawia podobieństwa i różnice między recenzją Jamesa pt. The Bethnal Green Museum, opublikowaną na łamach „Atlantic Monthly” w 1873 roku, i recenzją The Manchester Art Exhibition Nortona, opublikowaną w tym samym czasopiśmie około dwadzieścia lat wcześniej.

\section{Slowa kluczowe:}

Charles Eliot Norton, Henry James, Manchester Art Exhibition, Bethnal Green Museum

\footnotetext{
* Educated in Seoul, London and Cambridge. She currently teaches at Seoul National University as a parttime lecturer. Her Ph.D. thesis was on Henry James and the transatlantic periodical publishing practices. She has also written on Walter Pater and Jacques Rancière. E-mail: msy207@empas.com.
} 
$\mathrm{n}$ the early 1870s, Henry James wrote copious letters to Charles Eliot Norton, a co-editor of the North American Review (1865-1868) and a co-founder of the Nation (1865). James had found in Norton a mentor and guide to the field of periodical criticism, which Norton believed to be obliged to communicate the best thoughts of the Republic. Matthew Arnold's Essays in Criticism, which defended criticism as "a disinterested endeavour to learn and propagate the best that is known and thought in the world," 1 was the book James chose to review for the July issue of the North American Review in 1865 - the same year the Nation was launched with the claim that it would not be "the organ of any party, sect, or body" but would "make an earnest effort to bring to the discussion of political and social questions a really critical spirit." ${ }^{2}$ A series of letters from James to Norton in James's early career show an emerging novelist seeking confirmation of his project of producing fiction in terms of Norton's belief in the best standard. In a well-known letter of 1871, James accuses his friend, the novelist and critic William Dean Howells, whom Norton had recruited earlier as assistant editor of the Nation, on the grounds that he fails to bring "a really grasping imagination" to the problem of representing America in fiction. ${ }^{3}$ In the same year, James also singled out John Richard Dennett, who had been also appointed by Norton as a sub-editor to the Nation, as an example of "Americans of the younger sort" who are "unconscious and unambitious of the commission to do the best": Dennett, "who began with such excellent promise a few years ago[,] seems to have come to little."

James's apprenticeship to Norton, however, seems to have taken a distinct, if not a dramatic, turn by the end of the following year. In May 1872, James started his second European tour as an adult, escorting his sister Alice James. This journey, about which James published a series of correspondence in the Nation, subsequently to be collected in Transatlantic Sketches (1875), ended in mid-September after following the usual American route of a pseudo-Grand Tour from Liverpool through the Midlands to London, then on to Paris and the Swiss cities, and ending in Venice. In Paris, on his return journey, he met up with Norton, who had given up the editorship of the North American Review for health reason in 1868 and drifted around England and Europe ever since. Norton was spending the month of September in Paris after losing his wife. He was afterward to depart permanently for America. ${ }^{5}$ He had previously hosted James in 1869 in Lausanne, on James's first European tour as an adult. With the help of Norton, who had developed close friendships with British liberal intellectuals, James met John Ruskin, William Morris, Leslie Stephen, and many other British public figures, in both his first and second tours. In Paris in 1872, James was happy to be reunited with Norton, his ideal and practical guide to the transatlantic intellectual and art world, at the Louvre. This meeting, however, concluded with a feeling of alienation on James's side. His letter to William James is well known: “The Nortons are excellent, but I feel less and less at home with them, owing to a high moral je ne sais quoi which passes quite above my head." James continues that Norton "takes art altogether too

\footnotetext{
1 M. Arnold, Essays in Criticism, London 1875, p. 45.

2 Editorial [unsigned], The Nation 1 (1865), p. 1.

3 H. James, 17 January 1871, Letters: 1843-1875, vol. 1, ed. L. Edel, Cambridge, MA 1974, p. 252.

${ }^{4}$ Idem, 29 August 1871, Letters, op. cit., p. 26.

5 J. Turner, The Liberal Education of Charles Eliot Norton, Baltimore 1999, pp. 247-248.
} 
hard for me to follow him, - if not in his likings, at least in his dislikes. I daily pray not to grow in discrimination, and to be suffered to aim at superficial pleasure." James here sounds uncharacteristically like a flippant, youthful aesthete resisting the too-rigid judgments of an elder. Considering James's Nation travel correspondence published in 1872, this change was more than private: a tension that perhaps had always been latent in James, dampened by his anxiety for Norton's approval, was becoming more detectable in his public voice, too.

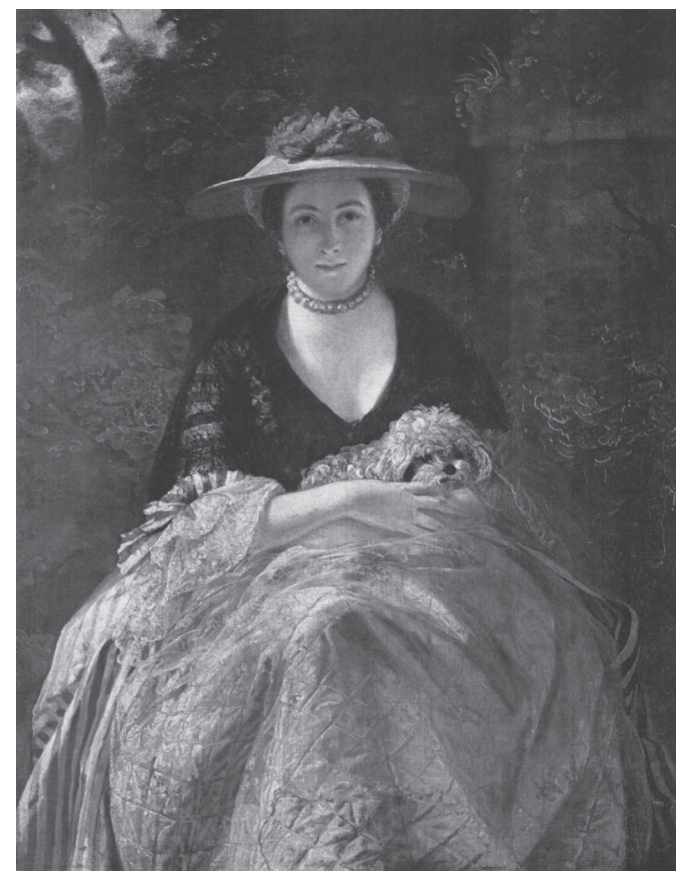

Joshua Reynolds, Nelly O’Brien. Photo by Wikimedia Commons

James wrote Norton that he was taking the ordinary American tourists' route to London from Liverpool via Chester "in the calmest, most prosaic manner" and had been "doing" the Haddon Hall "at one swoop." In "A European Summer, I: Chester" and "A European Summer, II: Lichfield and Warwick," however, James praised Chester with enthusiasm as "so rare and complete a specimen of an antique town" and also found the route to Haddon Hall highly poetic in leading him "to push forward with a rush, and emerge, and pause, and draw that first long breath which is the compromise between so many sensations." James may have been carrying out his duty as a travel correspondent in the expression of joyous sensation, but there seems some guilt at dissimulation in his accompanying note to Norton. Those travel letters which developed in a direction Howells found "metaphysical" 10 show him grappling with the contradictory expectations under which he laboured as a fresh,

6 H. James, 22 September 1872, op. cit., Letters, p. 300.

7 Idem, 1 June 1872, Letters, op. cit., p. 289.

8 Idem, "A European Summer, I: Chester," The Nation 15 (1872), p. 7.

9 Idem, "A European Summer, II: Lichfield and Warwick," The Nation 15 (1872), p. 57.

10 Howells to James, 1 September 1872, M. Anesko, Letters, Fictions and Lives: Henry James and William Dean Howells, New York 1997, p. 75. 
young travel writer and as a developing intellectual. He felt driven to deliver both the feeling of wonder customary at the first sight of European scenes and, at the same time, mature critical reflection on the meaning of these novel experiences. Jackson Lears has described Norton's approach to Europe as "aesthetic contemplation"-a conscious detachment that allowed him to reconcile his Puritan morality with Europe's decadent beauty. ${ }^{11}$ In the course of James's European correspondence for the Nation, we see the younger writer encountering the limitations of this aesthetic-moral program, and feeling the sharp need to create a different logic for understanding Europe and appreciating its artworks. James increasingly rejected Norton's aesthetic binary between artworks of deeper spiritual meaning and those that were merely pleasing. Ross Posnock has argued that, by the time of James's re-encounter with Norton at the Louvre, James came to be critical of Norton's "exclusionary" way of discriminating art while he himself was developing an "inclusive form of discrimination." 12 If we admit that James's defence of "superficial pleasure" was not a rejection of the critical act of discrimination, then, we cannot but be curious as to what James meant by "superficial" in 1872; and what, in particular, accelerated the divergence in aesthetics between James and Norton after James's visit, that year, to Venice - the perennial city of deep moral meaning for Norton, as it was for Ruskin.

I shall discuss in this paper another 1872 museum experience of James's, recorded in his article "The Bethnal Green Museum" in the January 1873 issue of the Atlantic Monthly, as a significant event which helped James to express his differentiated views on art and criticism from Norton's. James saw the newly-opened exhibition of paintings held at the Bethnal Green branch of the South Kensington Museum in October 1872 and wrote his review in Paris later that year. It should be noted that Norton had published a review article of his own, "The Manchester Art Exhibition," in the 1857 premiere issue of the Atlantic Monthly, announcing his future career as an art critic. In 1873, James turned to this magazine, which Howells edited at the time, instead of the Nation as an outlet for his travel writings from Rome. This move away from the Nation may be one indicator of a more conscious divergence from Norton's aesthetic values. In the 1860 s, Norton had been a contributor to the monthly-more populist, and more widely read, than the Nation. In the 1870s, however, Norton grew more dissatisfied with the market-conscious monthly, and especially its deliberate project to widen its readership by including mass-appeal fiction. In the heated unpublished correspondence between Norton and James in the wake of James's "Bethnal Green Museum" review, James revealed dissatisfaction with Dennett's editorial practices at the Nation, to which Norton responded: "I think you perverse in your feelings in regard to criticism. I can account for them only by the fact that you have read only the critical notices of the Atlantic Monthly of late." ${ }^{13}$ James had reason for being indignant, since Dennett had sent James's review of Middlemarch to the Galaxy "unrighteous[ly]" without seeking his solicitation - and had given other oblique signs of the Nation's dissatisfaction with James's travel writing. ${ }^{14}$ Norton, however, attributed James's anger to the Nation's critical rigour, thus revealing the extent to which he, too, had felt the tension of the meeting in the Louvre.

\footnotetext{
11 J. Lears, No Place of Grace, New York 1981, p. 247.

12 R. Posnock, The Trial of Curiosity: Henry James, William James, and the Challenge of Modernity, New York 1991, p. 197.

13 C. E. Norton, Letter to Henry James, 13 March 1873, Houghton, f. 377.

14 H. James, letter to Mrs. H. James, Sr., 17 February 1873, Letters, op. cit., p. 342.
} 
Norton lamented that James had not attended an exhibition of the Old Masters at the Royal Academy with him instead of reviewing the Bethnal Green show ${ }^{15}$ - as if the choice of review subject itself indicated the degradation of James's discriminatory powers. Catching the implication, James insisted: "I do, for instance, believe in criticism, more than that hyperbolical speech of mine would seem to suggest." ${ }^{16}$ If James's experience of the exhibition of the Bethnal Green Museum in 1872 was not the sole event demarcating his alienation from Norton's aesthetic vision and idea of criticism, it seems clear "The Bethnal Green Museum" review at least provided the momentum for James and Norton to reveal their differing views of professional art appreciation, especially in relation to the role of museums. I want to suggest that, as James's chosen outlet for this review, the Atlantic Monthly was cognate to the Bethnal Green Museum as more democratic spaces for the dissemination and appreciation of culture.

The structures and visualizing strategies of Norton's “The Manchester Art Exhibition” and James's “The Bethnal Green Museum” are quite similar, revealing that James was highly aware of the form and rhetoric of art criticism as developed by Norton for the American periodical readership. Norton opens his review by sketching the surroundings of the building that houses the exhibition, the Palace of the Exhibition of Art Treasures. Reminding American readers of the sketches of Manchester they may have seen in the "Illustrated News," Norton avers the reality of such scenes as "a thousand tall factory-chimneys rising out of a gray mist, and surmounted by a heavy, drifting cloud of smoke": if gallery-goers "turned and looked back before going within" the Exhibition hall, they could see that " $[t]$ wo miles off lies the body of the great work-shop city, already stretching its begrimed arms in the direction of the Exhibition." By this provision of a ground-level focal point to orient the reader, augmented by the tactile imagery of the encroaching "arms" of the ugly vista, the reader becomes the audience of a landscape painting of Manchester, dull in content but restless in its visual rhythm: "The vast flat expanse of brick walls, diversified by countless chimneys and occasional steeples, now and then interrupted by the insertion of a low shed or an enormous warehouse, offers no single object upon which the eye or the imagination can rest with pleasure." ${ }^{17}$ This opening gambit builds a sense of contrast between the scene beyond the gallery doors and that that greets viewers inside. Norton's implication is that an encounter with the "quietness and composure of solitary and delightful labor" will awaken in the audience an awareness of the unjustness of a world in which industrial labor dominates. ${ }^{18}$ For him, who in 1869 considered Britain's "social evils" so great that "the question is imminent whether the nation is to decline into a state of chronic decrepitude" or "to be redeemed by more or less violent revolution," 19 it was "a bold thought to bring pictures and statues into one great collection" and "to set off the art of the world against the manufactures of Manchester."20

\footnotetext{
15 C. E. Norton, Letter to Henry James, 19 January 1873, Houghton, f. 376.

16 H. James, 31 March 1873, Letters, op. cit., p. 362.

17 C. E. Norton, "The Manchester Art Exhibition," The Atlantic Monthly Nov. (1857), 1, p. 33.

18 Ibidem.

19 S. Norton and M. A. De Wolfe Howe, Letters of Charles Eliot Norton with Biographical Comments, Boston 1913, p. 329.

20 C. E. Norton, "The Manchester Art Exhibition," op. cit., p. 34.
} 
James adopts this strategy of Norton's, incorporating the geographical and social context of the gallery space itself into his appraisal of the impact of the exhibition. Crucially, however, James also reflects critically on the social meliorism implied in this very framing strategy. James begins his review with a reminder to the American reader of the popular English nursery ballad, “The Blind Beggar's Daughter of Bethnal Green.” The east London neighbourhood was known to Americans as a place languishing in the poverty of a more primitive age. James confirms that east London still has "beggary for its sign and token," and, like Norton, presents the museum at its heart as a place of contrasting cultural riches. This introduction evokes a visual fantasy for the American reader, as Norton's earlier piece does. James, however, works in a very different genre from the Nortonian landscape: he first writes without vivid visual association that “[the region's] wretchedness was so great that, till within a few months past, there may well have been a question whether a blind beggar was not rather a lucky person, and his imperfect consciousness a matter of congratulation." ${ }^{21}$ Then, after leading the reader through "an endless labyrinth of ever murkier and dingier alleys and slums," delaying and occluding the vision of what is to come, James suddenly unveils the Bethnal Green Museum as a treasure rich enough to put "a premium on good eye-sight." The social implications of this "premium" are developed as James suddenly pans out to observe the flow of visitors to the museum - not just of impoverished locals (at least on free entry days), but of "all of well-dressed London, flocking eastward to behold" the museum's treasures. ${ }^{22}$ This surprising change in perspective creates space for mordant irony: the museum is as much a pleasure ground for the fashionable as it is a device for perfecting the "imperfect consciousness" of the poor regarding their own wretchedness. James's cinematic change in focus between the near and far view of the Bethnal Green Museum in its social context contrasts strikingly with the neat symmetries of Norton's views toward and away from the Manchester museum's doors, which are supposed to create a neat division of the included and the excluded. If Norton's audience are invited to enjoy the exhibition inside the museum all the more sharply for their awareness of the ugliness and injustice outside, it is more difficult for the reader to sympathise with the exhibition-goer implied by James's review. James's strategy for describing the exhibition itself-which he prefaces by noting that art is less accessible for the uneducated, for reasons other than entry fees-is also learned largely from Norton's. However, it problematizes Norton's narrative method, which is embedded in a historical progressivism informed by Ruskin's idea of nature as the true essence both of the arts and of history.

Norton navigates sequentially from the entrance through the nave and aisles of the exhibition hall, where the modern sculptures are the first attraction. Passing swiftly on to the foreign painting section, Norton is instantly dissatisfied with the scarcity of works of the early Italian Renaissance, and with the near equal poverty - in quality, if not in quantityof Flemish and German works of the seventeenth century. To demonstrate its cause, he provides the American reader with an imaginary side-tour of a typical British palace or manor house's art collection, typically filled with "Titian, Van-dyck and Holbein." As these collections are the sources of the Manchester exhibition, Norton concludes, "it is not to be wondered at that it was difficult to form an historic sequence of pictures by which the course

\footnotetext{
21 H. James, “The Bethnal Green Museum," The Atlantic Monthly Jan. (1873), 31, p. 69.

22 Ibidem.
} 
and progress of Art should be properly illustrated, or that many of the old pictures that hang on the walls of the Exhibition bear the names of great masters than they deserve to be honored with." ${ }^{23}$

In criticizing the smugness of the British connoisseur's preference for secular pictorial works of the later Renaissance and the following period, Norton emphasizes the importance of the early Renaissance, when paintings were not loved simply as "objects of beauty or mere purpose of adornment" nor brought "into private homes with private means." 24 Then, he introduces Giotto, who is not well represented in the exhibition with only two minor works; he discusses the missing Duccio di Siena, complaining of the British preference for the Bolognese school's "academic accuracy" over Duccio's "better rendering of nature." 25 In other words, Norton fills the gaps in the unsatisfactory exhibition. The imperative to conjure absent masterpieces arises from Norton's belief that the greatest art captures not the seen but the unseen, a quasi-metaphysical quality which Ruskin named "nature." Consequently, Norton passes quickly over substantial parts of the exhibition that he considers less important - even the "realist" art that pays meticulous attention to nature in its sensible forms: the sixteenth-century Venetians-Bellini, Veronese and Giorgione, Titian and Tintoretto-are described with a sense of happy congruence between their importance and their predominant place in the exhibition, but Rembrandt and Ruisdael, and Murillo and Velasquez do not attract him "to pause" either "for study" or "for pleasure."26

In "The Bethnal Green Museum" James notes at the outset, as Norton does, the bias of the given exhibition. James sketches the Richard Wallace collection, whose transfer to the premises in 1872 at the expense of its eponymous owner essentially founded the Bethnal Green Museum, as a result of what Norton typified as English connoisseurship: "amusement rather than responsibility." ${ }^{27}$ James, however, does not attempt to outline a full history of art by summoning absent artworks; instead, he pays more attention to the works present, attempting to trace in them the subtle qualities he believes the best artworks possess. The most notable illustrations of the difference of James's approach is his treatment of the British painters Joshua Reynolds and Gainsborough, which Bethnal Green Museum considered its choicest holdings, and which had also been included in the Manchester Art Exhibition.

In "The Manchester Art Exhibition," Norton spends a considerable portion of his review on the British paintings, matching their dominant presence in the exhibition. He provides a narrative of British art history beginning around the turn of the eighteenth century, when taste was at a low ebb and "the artists, as a class, had given up the study of Nature as the foundation of Art; and in the place of Nature, they had put other men's pictures." 28 There then appeared, however, a true artist like Hogarth, who attempted to represent nature truthfully in defiance of painterly conventions. Norton also approves of the academician Reynolds - though he nevertheless considers him a bad influence on his followers-for breaking away from his stern theoretical conventionalism in a bid to represent nature more

23 C. E. Norton, "The Manchester Art Exhibition," op. cit., p. 35.

24 Ibidem, pp. 35-36.

25 Ibidem, p. 36.

Ibidem, p. 39.

H. James, "The Bethnal Green Museum," op. cit., p. 70.

C. E. Norton, "The Manchester Art Exhibition," op. cit., p. 42. 
faithfully in the actual paintings. In Norton's view, Reynolds's Nelly O'Brien, though not his best work, and Gainsborough's Blue Boy confirm their painters' status as true "students and renderers of human nature." ${ }^{29}$

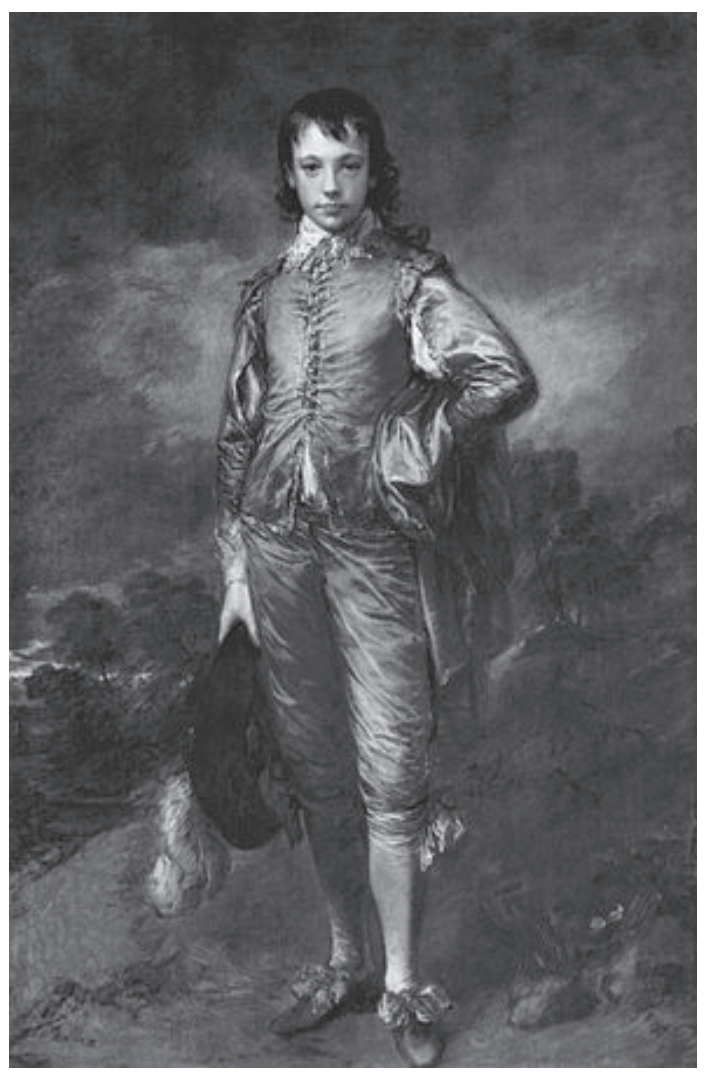

Thomas Gainsborough, The Blue Boy. Photo by Wikimedia Commons

James's contrasting treatment of Reynolds and Gainsborough is instructive of his aesthetic program. Eschewing an ambulatory, sequential account of his visit, James's review makes directly for these works, which are promoted by the museum as its most significant holdings: "The Bethnal Green catalogue opens with Sir Joshua Reynolds and Gainsborough, and it mentions no more delightful works than three or four first-rate examples of these deeply English painters. ${ }^{30}$ In this prioritising gesture, James does what an American lay visitor to the exhibition - the petit-bourgeois tourist of the late Grand Tour-might choose to do. James lavishes each of the prestigious pictures with detailed attention, offering minimal historical context. He thus gives preeminence to the phenomenological encounter with the individual art masterpiece, over the (implicitly conservative and elitist) mediating force of art history-even though he was aware an actual American tourist would almost certainly have encountered these paintings in second-hand accounts-in the Museum catalogue if not elsewhere-before meeting them in the gallery.

29 Ibidem, p. 43.

30 H. James, "The Bethnal Green Museum," op. cit., p. 70. 
James sums up his critical judgment of these British painters thus: "There is something, to our perception, so meagre and ineffective in the English pictorial effort in general, that when it asserts itself, as in these cases, with real force and grace, it stirs in the sensitive beholder a response so sympathetic as to be almost painful." It should be noted here that, while seeming to agree with Norton about the mediocrity of the achievement of the British painters, James in fact emphasizes the extraordinary merits of these specific works. James goes on to argue that " $\mathrm{t}]$ he merit is not at all school-merit, and you take very much the same sort of affectionate interest in it as you do in the success of a superior amateur."31 While James may sound Nortonian in his finding that perfected technique is not the highest value in pictorial representation, his attention to the affect created by the artworks on the viewer-feeling, undefinable in words, strong enough to cause a bodily pain-is a huge departure from Norton's critical perspective. Norton, in spite of his opposition to classical conventionalism, prioritises pictures with nobler subject matter which he believes to enhance the beholder's noble emotion and ability to read into the hidden meaning of the world. Norton finds the "happy picture of a girl" Nelly O'Brien to be one of Reynolds's minor works ${ }^{32}$ for the reason of the portrayed girl's humble characteristics, while James sees it as exerting "real force" on the beholder. ${ }^{33}$ James invokes and dismisses the view of unnamed other critics that there is a similarity "[i]n a certain easy, broad felicity" with Titian's Bella Donna, arguing that, in Nelly O'Brien, "[c] haracter plays up into the English face with a vivacity unmatched in that of Titian's heroine." Despite the inclusion of the qualifier "English," James sees the sitter's intense individuality, rather than her representativeness of a national type- "broad felicity" - as the key element that creates the power of the picture. ${ }^{34}$ In its singularity, the Reynolds even surpasses Titian, James thinks, and marks the Englishman out as an "instinctive colorist." 35

James honours his exceptional admiration of Nelly O'Brien's pictorial charms in a singularly wordy description: one column, or half of one page, of the Atlantic Monthly review is dedicated to its examination. Certainly, this is not just an appreciation of pure painterly form, but includes biographical interpretation: "She melted many hearts, we conjecture, but she broke none; though a downright beauty, she was not a cruel one, and on her path through life she stirred more hope than despair." ${ }^{36}$ However, James is not a hermeneutician in the sense of Norton who sees "words as the symbols of thought." ${ }^{37}$ It is crucial, moreover, that James emphasized a "painful" feeling as the first response to the picture, ${ }^{38}$ a somaticaesthetic encounter irreducible to the fantasy biography he conjures as a "happy" story, like Norton, from the sitter's placid stance and expression. ${ }^{39}$

In terms of art history, what James suggests by defending Reynolds's "color" seems to be an impressionist one, as Bonnie MacDonald argued of James's travel narrative tech-

31 Ibidem.

32 C. E. Norton, "The Manchester Art Exhibition," op. cit., p. 43.

33 H. James, "The Bethnal Green Museum," op. cit., p. 70.

34 Ibidem.

35 Ibidem.

36 Ibidem.

37 "Reviews and Literary Notices [Le Prime Quattro Edizione della Divina Commedia]," The Athlantic Monthly May, 5 (1860), p. 627.

38 H. James, "The Bethnal Green Museum," op. cit., p. 70.

39 Ibidem, p. 71; cf. C. E. Norton, "The Manchester Art Exhibition," op. cit., p. 43. 
nique in Henry James's Italian Hours: Revelatory and Resistant Impressions. ${ }^{40}$ James admires "the full ripe countenance she presents to us, slightly flattened and suffused by the shadow in which she sits," revealing a preoccupation with light and colour which continues in his observation of the "watery English sunlight" that "compels the broken tones of silk and satin into a delicious silvery harmony; and hanging in there in its crepuscular London atmosphere, the picture has a hardly less distinct individuality of coloring" than the Veronese of the Ducal Palace reflected in the Venetian Lagoon. ${ }^{41}$ In contrast with Norton, who asserts that "Sir Joshua does not compare with Gainsborough in landscape,"42 James's comparison of Reynolds and Veronese nullifies the conventional distinction of the genres of portrait and landscape, and brings a minor work and a major masterpiece into purely pictorial constellation. This is not to say that James achieves — or aims at - a complete divorcing of colour and light from subject matter. The painting's superb handling of colour is in the service, in James's view, of the important task of sensitizing viewers to the singularity and significance of any humble human life. The intuition of this fact is the source of the painting's initial "painful" effect on the viewer, who confronts the opacity of the meaning of any singular existence. ${ }^{43}$ The uncomfortable dissonance between the Bethnal Green Museum and its impoverished surroundings reverberates, in James's sensitive review, this instant pain which arises from the incommensurability of existence and interpretation.

What James saw in and around the Bethnal Green Museum was the arrogance behind the conception of "this experimental lever for the elevation of the masses," 4 and the many obstacles poor visitors would face in meaningfully encountering the individual works on display. In this, James undermined the earlier optimism of Norton and other commentators about the power of art to ameliorate injustice and enlighten the poor through sheer spiritual transcendence. In Venice, too-for Norton, the source of a rich tropology for understanding the potential salvation of an American republic at risk of atrophying in its pursuit of mere material wealth—what James had seen was the "mocking, elusive soul of things" instead of a revelation of providential history. ${ }^{45}$ James does not, however, deny the affective power of the city of Venice over the mere tourist, nor that its pictures speak eloquently to the sensitive lay viewer. Despite the opaqueness he detects in the city, which works against the interpretation of its tropological meaning, Venice is able to awaken the consciousness of perceptive viewers to the diverse singularity of human existence. James feared Norton lacked this consciousness, and was thus on the path to becoming a facile pessimist about the future of the post-Civil War America, thanks to a rigidly idealistic view of art and criticism that denounced what it could not interpret.

James instead resolved "to be suffered to aim at superficial pleasure," as if this were a moral duty requiring his martyrdom ${ }^{46}$ — precisely because he opposed Norton's division of the world into those inside and those outside the privileged space of "genuine" art appreciation. His mission was to defend artworks that rendered secular lives in their colorful

\footnotetext{
40 B. MacDonald, Henry James's 'Italian Hours': Revelatory and Resistant Impressions, Ann Arbor 1990.

41 H. James, "The Bethnal Green Museum," op. cit., pp. 70-71.

42 C. E. Norton, "The Manchester Art Exhibition," op. cit., p. 43.

43 H. James, "The Bethnal Green Museum," op. cit., p. 70.

44 Ibidem, p. 69.

45 H. James, "A European Summer, VII: From Venice to Strasbourg," The Nation 16 (1873), p. 164.

46 H. James to W. James, 22 September 1872, Letters, op. cit., p. 300.
} 
and irreducible variety, though their resistance to easy interpretation might make them appear superficial - and therefore, to defend as the legitimate subjects and appreciators of art the lay American audience shunned by Norton and the Nation, as well as the poor who walked daily past the doors of the Bethnal Green Museum and who, he hoped, would increasingly walk in to make their own encounters.

\section{Bibliography}

Anesko, Michael, ed. Letters, Fictions and Lives: Henry James and William Dean Howells. New York:

Oxford University Press, 1997.

Arnold, Matthew. Essays in Criticism. Vol. 1. London: Macmillan. 2 vols., 1875.

James, Henry. "A European Summer, I: Chester." The Nation 15 (1872).

—. "A European Summer, II: Lichfield and Warwick." The Nation 15 (1972).

—. "The Bethnal Green Museum." The Atlantic Monthly Jan. (1873).

—. "A European Summer, VII: From Venice to Strasbourg." The Nation 16 (1873).

—. Letters: 1843-1875. Ed. Leon Edel. Vol. 1. Cambridge, MA: Belknap, 1974. 4 vols., 1974-1984.

Lears, Jackson. No Place of Grace. New York: Pantheon, 1981.

MacDonald, Bonnie. Henry James's Italian Hours: Revelatory and Resistance Impressions. Ann Arbor, MI: UMI Research Press, 1990.

Norton, Charles Eliot. “The Manchester Art Exhibition." The Atlantic Monthly Nov. (1857).

—. "Reviews and Literary Notices [Le Prime Quattro Edizione della Divina Commedia]." The Atlantic Monthly May, 5 (1860).

-. 1873. Letter to Henry James. 19 January. MS. Henry James, Jr. Papers (Am 1094, f. 376). Houghton Lib. Harvard University, Cambridge, MA.

—. Letter to Henry James. 13 March 1873. MS. Henry James, Jr. Papers (AM 1094, f. 377). Houghton Lib. Harvard University, Cambridge, MA.

Norton, Sara, and Mark A. De Wolfe Howe. Letters of Charles Eliot Norton with Biographical Comments. Vol. 1. Boston: Houghton Mifflin. 2 vols., 1913.

Posnock, Ross. The Trial of Curiosity: Henry James, William James, and the Challenge of Modernity. New York: Oxford University Press, 1991.

Turner,James. The Liberal Education of Charles Eliot Norton. Baltimore: The Johns Hopkins University Press, 1999.

Unsigned. Editorial. The Nation 1 (1865). 